\title{
TINGKAT KEPUASAN PASIEN TERHADAP KUALITAS PELAYANAN DI INSTALASI FARMASI RUMAH SAKIT ISLAM PKU MUHAMMADIYAH PALANGKARAYA
}

\author{
Evi Mulyani
}

Dosen Program Studi D-III Farmasi Universitas Muhammadiyah Palangkaraya

\begin{abstract}
ABSTRAK
Berdasarkan observasi langsung yang dilakukan oleh peneliti, tidak jarang pasien yang berkunjung ke Instalasi Farmasi RS Islam PKU Muhammadiyah Palangkaraya mengeluh atas ketidakpahaman mengenai alur pelayanan hal ini diduga karena belum tersedianya fasilitas visual penunjuk alur pelayanan kesehatan dan adanya keluhan pasien akan ketersediaan obat yang kurang.

Penelitian ini bertujuan untuk mengetahui tingkat kepuasan pasien terhadap kualitas pelayanan di Instalasi Farmasi Rumah Sakit Islam PKU Muhammadiyah Palangkaraya berdasarkan lima dimensi kualitas jasa. Metode penelitian ini bersifat deskripstif dengan jumlah populasi 700 orang.

Jumlah sampel pada penelitian ini sebanyak 90 orang. Data dikumpulkan menggunakan kuesioner tertutup yang berisi beberapa pernyataan. Kuesioner dibagikan langsung kepada 90 orang responden yaitu pasien rawat jalan/pendamping pasien rawat jalan, dalam hal ini pendamping pasien rawat jalan adalah orang yang menemani/mengantarkan pasien rawat jalan yang menerima pelayanan farmasi di Instalasi Farmasi Rumah Sakit Islam PKU MuhammadiyahPalangkaraya. Pengambilan sampel pada penelitian ini menggunakan purposive sampling. Analisis data yang digunakan dalam penelitian ini menggunakan format jawaban Skala Likert.

Dari hasil penelitian yang diperoleh, tingkat kepuasan pasien terhadap kualitas pelayanan farmasi berdasarkan lima dimensi kualitas jasa yang dikemukakan oleh Parasuranman, Zeithmal, dan Berry adalah Dimensi bukti langsung (Tangible)76,1\% yang masuk dalam kategori puas, Kemampuan (Reability) 73,3\% masuk dalam kategori puas, Daya tanggap (Responsivnes) $75,7 \%$ dalam kategori puas, Jaminan (Assurance) $72,2 \%$ masuk dalam kategori puas, serta dimensi Perhatian (Emphaty) $74,3 \%$ dalam kategori puas.
\end{abstract}

Kata kunci: Tingkat Kepuasan Pasien, Pelayanan Farmasi, Dimensi Kualitas Jasa.

\section{PENDAHULUAN}

Pelayanan yang berkualitas dapat dilihat salah satunya dengan tingkat kepuasan konsumen atau pasien. Kepuasan menjadi bagian penting dalam pelayanan kesehatan sebab kepuasan pasien tidak dapat dipisahkan dari kualitas pelayanan kesehatan. Jika kita akan melakukan upaya peningkatan kualitas pelayanan maka diperlukan adanya survey dari tingkat kepuasan konsumen atau pasien. Menurut Parasuraman, Zeithmal dan Berry ada lima dimensi kualitas jasauntuk melihat kepuasan konsumen atau pasien yang dikenal dengan nama Serv Qual. Kelima dimensi tersebut meliputi Tangible (bukti langsung), Realibility (Kehandalan), Respomsiveness (Daya tanggap), Assurance (Jaminan) dan Emphaty (Perhatian) (Muninjaya, 2014).

Melihat akan pentingnya kepuasan pasien dalam memperoleh pelayanan kesehatan yang bermutu maka instansi 
penyedia jasa pelayanan kesehatan seperti rumah sakit hendaknya menyediakan pelayanan yang dapat memberikan kepuasan pada pasien atau konsumen yang memperoleh jasa pelayanan kesehatan sebab persepsi pasien akan mutu pelayanan kesehatan yang baik akan menumbuhkan rasa loyalitas pasien pada instansi penyedia jasa pelayanan kesehatan tersebut. Halini juga berlaku pada rumah sakit swasta karena dalam era persaingan global ini rumah sakit swasta dituntut memberikan pelayanan prima yang jauh lebih baik dari rumah sakit pemerintah pada umumnya.

Berdasarkan observasi langsung yang dilakukan oleh peneliti, tidak jarang pasien yang berkunjung ke Instalasi Farmasi RS Islam PKU Muhammadiyah Palangkaraya mengeluh atas ketidakpahaman mengenai alur pelayanan hal ini diduga karena belum tersedianya fasilitas visual penunjuk alur pelayanan kesehatan, dan adanya keluhan pasien akan ketersediaan obat yang kurang hal ini sejalan dengan hasil penelitian Astuti (2013) tentang Evaluasi Mutu Pelayanan IFRS RS Islam PKU Muhammadiyah Palangkaraya Berdasarkan Ketersediaan Obat Yang Diresepkan Periode Januari-Mei 2013 menyatakan bahwa ketersedian obat di Instalasi Farmasi Rumah Sakit Islam PKU Muhammadiyah Palangkaraya belum mencapai $100 \%$ disebabkan karena aspek perencanaan obat belum optimal dan tidak adanya stok pengaman serta tidak adanya acuan tetap bagi dokter dalam menuliskan resep kemudian dari hasil penelitian Rusmiati (2013) tentang Evaluasi Mutu Pelayanan K.I.E Di IFRS RS Islam PKU Muhammadiyah Palangkaraya menyatakan bahwa penyampaian K.I.E dalam penyerahan obat telah dilakukanakan tetapi tidak sepenuhnya diberikan hal tersebut disebabkan oleh waktu yang tersedia dianggap kurang untuk farmasis menyampaikan K.I.E.

Berdasarkan latar belakang diatas penulis tertarik melakukan penelitian tentang Tingkat Kepuasan Pasien Rawat Jalan Terhadap Kualitas Pelayanan Dilnstalasi Farmasi Rumah Sakit Islam PKU Muhammadiyah Palangkaraya menggunakan lima dimensi kualitas jasa untuk mengetahui tingkat kepuasan pasien, kelima dimensi tersebut meliputi Tangible (bukti langsung), Realibility (Kehandalan), Respomsiveness (Daya tanggap), Assurance (Jaminan) dan Emphaty (Perhatian). Pasien yang merasa puas dengan jasa pelayanan yang diterimanya akan memperlihatkan kecenderungan yang besar untuk menggunakan kembali jasa yang ditawarkan oleh pemberi jasa tersebut dimasa yang akan datang.

\section{METODE PENELITIAN}

\section{Tempat dan Waktu Penelitian}

Penelitian ini dilaksanakan pada bulan Februari 2016 - Mei 2016 di Instalasi Farmasi RSI PKU Muhammadiyah Palangkaraya. 


\section{Metode Penelitian}

Penelitian ini merupakan penelitian non-eksperimental. Metode yang digunakan dalam penelitian ini adalah metode deskriptif. Dalam penelitian ini dimaksudkan untuk mendapat gambaran kepuasan pasien yang datang ke Instalasi Farmasi RS RSI PKU Muhammadiyah Palangkaraya terhadap kualitas pelayanan yang ada di Instalasi Farmasi RSI PKU Muhammadiyah Palangkaraya.

\section{Populasi dan Sampel}

Populasi yang digunakan dalam penelitian ini adalah seluruh pasien rawat jalan/pendamping pasien rawat jalan yang mendapatkan pelayananfarmasi di IFRS RSI PKU Muhammadiyah Palangkaraya dengan jumlahrata-rata 700 orang per bulan.

Jumlah sampel dalam penelitian ini menggunakan rumus Slovin (Umar, 2014) yaitu sebesar 90 Responden. Pengambilan sampel pada penelitian ini berdasarkan teknik purposive sampling. Dalam penelitian ini sampel/responden yang dipilih adalah pasien rawat jalan atau pendamping pasien rawat jalan dari bagian poliklinik yang mendapat pelayanan farmasi dan dianggap peneliti mampu berkomunikasi dengan baik sehingga dapat mempertanggung jawabkan apa yang telah ia kemukakan.

\section{Variabel Penelitian}

1. Variabel Independen

Adapun variabel bebas pada penelitian ini adalah kualitas pelayanan farmasi dilnstalasi Farmasi RSI PKU Muhammadiyah Palangkaraya

2. Variabel Dependen

Kepuasan pasien di Instalasi Farmasi RSI PKU Muhammadiyah Palangkaraya.

\section{Definisi Operasional}

1. Pasien: Seseorang yang berobat jalan dan mendapatkan pelayanan farmasi di Instalasi Farmasi RSI PKU Muhammadiyah Palangkaraya

2. Pelayanan : Semua jenis pelayanan farmasi yang diberikan oleh petugasfarmasi di Instalasi Farmasi RSI PKU Muhammadiyah Palangkaraya kepada pasien yang mendapatkan pelayanan.

3. Kepuasan : Tingkat keadaan yang dirasakan pasien merupakan hasil darimembandingkan penampilan atau hasil produk yang dirasakan dalam hubungannya dengan harapan seseorang.

4. Tingkat kepuasan : Jika penampilan/pelayanan sangat kurang dari harapan, pasien sangat tidak dipuaskan dan diberi skor 1. Jika penampilan/pelayanan kurang dari harapan, pasien tidak dipuaskan dan diberi skor $2 . \quad$ Jika penampilan/pelayanan mencukupi dari harapan, pasien cukup dipuaskan dan diberi skor $3 . \quad$ Jika 
penampilan/pelayanan sebanding dengan harapan, pasien puas dan diberi skor 4 . Jika penampilan/pelayanan lebih dari harapan, pasien sangat dipuaskan dan diberi skor 5 .

\section{Instrumen Penelitian}

Instrumen penelitian yang digunakan pada penelitian ini adalah kuesioner yang diuji menggunakan uji validitas dan uji realibilitas.

\section{Teknik Pengumpulan Data}

Teknik pengumpulan data yang akan digunakan adalah data primer dan data sekunder. Data primer diperoleh melalui kuesioner yang disebarkan kepada responden yang menjadi subjek penelitian. Data sekunder diperoleh dari bagian rekam medik untuk mengetahui jumlah kunjungan pasien rawatjalan.

\section{Teknik Analisa Data}

Teknik analisis data yang digunakan dalam proses penelitian ini adalah:

1. Uji validitas

Uji validitas yaitu suatu alat ukur yang digunakan untuk mengukur sahatau valid tidaknya suatu butir pertanyaan. Suatu pengukuran yang dikatakan valid bila nilai korelasi $>0,361$ (Sugiyono, 2015)

2. Uji Reliabilitas

Uji reliabilitas yaitu suatu alat ukur yang menunjukkan seberapa besar suatu instrument tersebut dapat dipercaya dan digunakan sebagai alat pengumpul data.
Suatu pengukuran yang dikatakan reliable bila nilaiacronbach $>0,60$ (Siregar, 2010). Uji validitas dan reabilitas menggunakan uji korelasi parametrik maka jumlah minimal responden yang digunakan adalah sebanyak 30 orang. jumlah ini dianggap cukup untuk mewakili populasi.

\section{Persentase}

Data yang dikumpulkan kemudian dibuat dalam bentuk tabulasi dan dianalisis serta dibuat pembahasan dan kesimpulannya. Teknik analisis dalam penelitian ini menggunakan rumus persentase.

$\mathrm{P}=\mathrm{F} / \mathrm{N} \times 100$

$$
\begin{gathered}
\text { Ket : P (Persentase) } \\
\text { F (Frekuensi) } \\
\text { N (Responden) }
\end{gathered}
$$

\section{Skala Likert}

Analisis skor tingkat kepuasan pada penelitian ini menggunakan format jawaban Skala Likert yang memungkinkan pasien menjawab dalam berbagai tingkatan (1-5) dimana setiap jawaban diberi bobot nilai dengan ketentuaan sebagai berikut (Riduwan, 2013).

a. Skor 5 bila jawaban "Sangat Puas"

b. Skor 4 bila jawaban "Puas"

c. Skor 3 bila jawaban "Cukup Puas"

d. Skor 2 bila jawaban "Tidak Puas"

e. Skor 1 bila jawaban "Sangat Tidak Puas" Kriteria interpretasi skor menurut Skala Likert dalam pengukuran tingkat kepuasan adalah sebagai berikut :
a. Angka $0 \%-20 \%$ = Sangat Tidak Puas
b. Angka $21 \%-40 \%=$ Tidak Puas
c. Angka $41 \%-60 \%$ = Cukup Puas 
d. Angka $61 \%-80 \%=$ Puas

e. Angka $81 \%-100 \%$ = Sangat Puas

(Riduwan, 2007).

\section{HASIL DAN PEMBAHASAN}

Hasil

Tabel 1. Kualitas jasa berdasarkan bukti fisik (Tangible)

\begin{tabular}{|c|c|c|c|c|}
\hline No & Bukti Fisik & Skor & Persen & Ket \\
\hline 1 & $\begin{array}{lr}\text { Fasilitas } & \text { dan } \\
\text { sarana yang } \\
\text { dimiliki berfungsi } \\
\text { dengan baik }\end{array}$ & 346 & $76,9 \%$ & Puas \\
\hline 2 & $\begin{array}{l}\text { Kebersihan } \\
\text { Lingkungan } \\
\text { dipeliharaDengan } \\
\text { Baik. }\end{array}$ & 344 & $76,4 \%$ & Puas \\
\hline 3 & $\begin{array}{ll}\text { Suasana } & \text { ketika } \\
\text { berada } & \text { dalam } \\
\text { ruang tunggu } & \\
\text { menyenangkan }\end{array}$ & 337 & $74,9 \%$ & Puas \\
\hline & Rata-rata & $\begin{array}{l}342, \\
3\end{array}$ & $76,1 \%$ & Puas \\
\hline
\end{tabular}

Tabel 2. Kualitas jasa berdasakan keampuan (reliabity

\begin{tabular}{|c|l|l|l|l|}
\hline $\begin{array}{l}\mathrm{N} \\
\mathrm{O}\end{array}$ & Kemampuan Skor & Persen & Ket \\
\hline 1 & $\begin{array}{l}\text { Petugas farmasi } \\
\text { mampu menangani } \\
\text { tanya jawab para } \\
\text { Pasien secara baik dan } \\
\text { tepat }\end{array}$ & 325 & $72,2 \%$ & Puas \\
\hline 2 & $\begin{array}{l}\text { keterampilan petugas } \\
\text { sangat baik dalam } \\
\text { memberikan pelayanan }\end{array}$ & 333 & $74,0 \%$ & Puas \\
\hline 3 & $\begin{array}{l}\text { prosedur pelayanan } \\
\text { farmasi yang mudah } \\
\text { dan tidak berbelit-belit }\end{array}$ & 331 & $73,6 \%$ & Puas \\
\hline \multicolumn{2}{|l|}{ Rata-rata } & 329,7 & $73,3 \%$ & Puas \\
\hline
\end{tabular}


Tingkat Kepuasan Pasien Terhadap Kualitas Pelayanan Di Instalasi Farmasi Rumah Sakit Islam Pku Muhammadiyah Palangkaraya

Tabel 3. Kualitas jasa berdasarkan daya tanggap (Responsivness)

\begin{tabular}{|l|l|l|l|l|}
\hline $\begin{array}{l}\mathrm{N} \\
\mathrm{O}\end{array}$ & Daya Tanggap & Skor & Persen & Ket \\
\hline 1 & $\begin{array}{l}\text { Petugas farmasi siap } \\
\text { dan tanggap dalam } \\
\text { melayani pasien }\end{array}$ & 331 & $73,6 \%$ & Puas \\
\hline 2 & $\begin{array}{l}\text { Petugas farmasi ramah } \\
\text { dalam melayani para } \\
\text { pasien. }\end{array}$ & 348 & $77,3 \%$ & Puas \\
\hline 3 & $\begin{array}{l}\text { petugas farmasi tidak } \\
\text { terburu-buru dalam } \\
\text { melayani pasien }\end{array}$ & 343 & $76,2 \%$ & Puas \\
\hline \begin{tabular}{l} 
Rata-rata \\
\hline
\end{tabular} & 340,7 & $75,7 \%$ & Puas \\
\hline
\end{tabular}

Tabel 4. Kualitas jasa berdasarkan jaminan (Assurance)

\begin{tabular}{|l|l|l|l|l|}
\hline No & Jaminan & Skor & Persen & Ket \\
\hline 1 & $\begin{array}{l}\text { Petugas farmasi } \\
\text { secara konsisten } \\
\text { bersikap sopan }\end{array}$ & 324 & $72,0 \%$ & Pua \\
\hline 2 & $\begin{array}{l}\text { Petugas farmasi } \\
\text { dapatmenumbuhkan } \\
\text { rasa percaya para } \\
\text { pasien }\end{array}$ & 347 & $77,1 \%$ & Pua \\
\hline 3 & $\begin{array}{l}\text { Tersedianya jaminan } \\
\text { ketersediaan } \\
\text { obat }\end{array}$ & 304 & $67,6 \%$ & Pua \\
\hline & Rata-rata & 340, & $72,2 \%$ & Pua \\
\hline
\end{tabular}


Tabel 5. Kualitas jasa berdasarkan perhatian (Emphaty)

\begin{tabular}{|l|l|l|l|l|}
\hline No & Emphaty Skor & Persen & Ket \\
\hline 1 & $\begin{array}{l}\text { Pelayanan farmasi memberikan } \\
\text { pelayanan yang sama tidak } \\
\text { membedakan pasien }\end{array}$ & 328 & $72,9 \%$ & Puas \\
\hline 2 & $\begin{array}{l}\text { Petugas farmasi penuh } \\
\text { perhatian dan sabar dalam } \\
\text { memahami kebutuhan pasien } \\
\text { dan memberikan solusi }\end{array}$ & 349 & $77,6 \%$ & Puas \\
\hline 3 & $\begin{array}{l}\text { Petugas farmasi menciptakan } \\
\text { suasana nyaman selama pasien } \\
\text { menunggu obat }\end{array}$ & 326 & $72,4 \%$ & Puas \\
\hline & Rata-rata & 334,6 & $74,3 \%$ & Puas \\
\hline
\end{tabular}

\section{Pembahasan}

Dapat dilihat dalam tabel 1 diatas hasil skor tingkat kepuasan pasien pada dimensi bukti fisik (Tangible) terhadap kualitas pelayanan farmasi berdasarkan data yang diperoleh dari 90 orang responden. Dimensi bukti fisik (Tangible) meliputi fasilitas fisik yang mencakup kondisi sarana, kondisi sumber daya manusia dan keselarasan antara fasilitas fisik dengan jenis jasa yang diberikan (Tjiptono, 2006). Dalam penelitian ini dimensi bukti fisik meliputi fasilitas dan sarana yang disediakan, kebersihan disekitar lingkungan dan suasana di dalam ruang tunggu yang ada di Instalasi Farmasi RS Islam PKU Muhammadiyah Palangkaraya. Gambaran persepsi pasien rawat jalan/pendamping pasien rawat jalan mengenai fasilitas dan sarana yang disediakan diperoleh hasil data skor 346 dan persentase interpretasi skor 76,9\%. Dari data tersebut menunjukan bahwa sebagian responden puas terhadap fasilitas dan sarana yang disediakan. Sedangkan gambaran persepsi pasien rawat jalan/pendamping pasien rawat jalan mengenai kebersihan disekitar lingkungan diperoleh hasil data skor 344 dan persentase interpretasi skor 76,4\%. Dari data tersebut menunjukan bahwa sebagian responden puas terhadap kebersihan disekitar lingkungan. Untuk gambaran persepsi pasien rawat jalan/pendamping pasienrawat jalan mengenai suasana di dalam ruang tunggu diperoleh hasil data skor 337 dan persentase interpretasi skor $74,9 \%$. Dari data tersebut menunjukan bahwa sebagian responden puas terhadap suasana di dalam ruang tunggu.

Dari ketiga data tersebut dapat ditarik kesimpulan bahwa tingkat kepuasan pasien berdasarkan dimensi bukti fisik (Tangible) diperoleh rata-rata data skor sebesar 342,3 dengan rata-rata persentase interpretasi sebesar $76,1 \%$ yang menunjukan bahwa sebagian besar responden puas terhadap pelayanan berdasarkan dimensi bukti fisik (Tangible). Hal ini dapat dikarenakan oleh fasilitas fisik layanan yang tersedia telah memadai 
sehingga pelayanan sebanding dengan harapan pasien.

atas hasil skor tingkat kepuasan pasien pada dimensi kemampuan (Realibility) terhadap kualitas pelayanan farmasi berdasarkan data yang diperoleh dari 90 orang responden. Dimensi kemampuan (Realibility) meliputi pelayanan yang disajikan dengan segera, kepedulian pada permasalahan yang dialami pasien, kehandalan penyampaian jasa dan ketepatan waktu dalam pelayanan (Tjiptono, 2006).

Dalam penelitian ini dimensi kemampuan (Realibility) meliputi kemampuan petugas menangani tanya jawab pasien, keterampilan petugas dalam memberikan pelayanan dan prosedur pelayanan yang mudah. Gambaran persepsi pasien rawat jalan/pendamping pasien rawat jalan mengenai kemampuan petugas menangani tanya jawab pasien diperoleh hasil data skor 325 dan persentase interpretasi skor 72,2\%. Dari data tersebut menunjukan bahwa sebagian besar responden puas terhadap kemampuan petugas menangani tanya jawab pasien. Gambaran persepsi pasien rawat jalan/pendamping pasien rawat jalan mengenai keterampilan petugas dalam memberikan pelayanan diperoleh hasil data skor 333 dan persentase interpretasi skor $74,0 \%$. Dari data tersebut menunjukan bahwa sebagian besar responden puas terhadap keterampilan petugas dalam memberikan pelayanan. Gambaran
Dapat dilihat pada tabel $2 \mathrm{~d}$

persepsi pasien rawat jalan/pendamping pasien rawat jalan mengenai prosedur pelayanan yang mudah diperoleh hasil data skor 331 dan persentase interpretasi skor $73,6 \%$. Dari data tersebut menunjukan bahwa sebagian besar responden puas terhadap prosedur pelayanan yang mudah.

Dari ketiga data tersebut dapat ditarik kesimpulan bahwa tingkat kepuasan pasien berdasarkan dimensi kualitas jasa kemampuan (Realibility) diperoleh rata-rata data skor sebesar 329,7 dengan rata-rata persentase interpretasi sebesar $73,3 \%$. Dari nilai rata-rata skor dan interpretasi skor tersebut menunjukan bahwa sebagian besar responden puas terhadap pelayanan berdasarkan dimensi kemampuan (Realibility). Hal tersebut dapat dikarenakan oleh kemampuan petugas dalam memberikan pelayanan kesehatan telah baik dan tepat sehingga pelayanan tersebut dirasa pasien/pendamping pasien rawat jalan sebanding dengan harapan yang dirasakannya.

Dapat dilihat pada tabel 3 hasil skor tingkat kepuasan pasien pada dimensi daya tanggap (Responsivness) terhadap kualitas pelayanan farmasi berdasarkan data yang diperoleh dari 90 orang responden. Dimensi daya tanggap (Responsivness) adalah keinginan petugas untuk membantu dan menyediakan jasa yang dibutuhkan pasien. Hal ini meliputi kejelasan informasi waktu penyampaian 
jasa, ketepatan dan kecepatan dalam pelayanan farmasi, kesedian petugas dalam membantu pasien dan keluangan waktu petugas dalam menanggapi permintaan pasien (Tjiptono, 2006).

Dalam penelitian ini dimensi daya tanggap (Responsivness) meliputi kesiapan dan ketanggapan petugas dalam pelayanan, keramahan petugas dalam pelayanan dan keluangan waktu petugas dalam memberikan pelayanan yang ada di Instalasi Farmasi RS Islam PKU Muhammadiyah Palangkaraya. Gambaran persepsi pasien rawat jalan/pendamping pasien rawat jalan mengenai kesiapan dan ketanggapan petugas dalam pelayanan diperoleh hasil data skor 331 dan persentase interpretasi skor 73,6\%. Dari data tersebut menunjukan bahwa sebagian besar responden puas terhadap kesiapan dan ketanggapan petugas dalam pelayanan. Gambaran persepsi pasien rawat jalan/pendamping pasien rawat jalan mengenai keramahan petugas dalam pelayanan diperoleh hasil data skor 348 dan persentase interpretasi skor $77,3 \%$. Dari data tersebut menunjukan bahwa sebagian besar responden puas terhadap keramahan dalam pelayanan. Gambaran persepsi pasien rawat jalan/pendamping pasien rawat jalan mengenai keluangan waktu petugas dalam memberikan pelayanan diperoleh hasil data skor 343 dan persentase interpretasi skor $76,2 \%$. Dari data tersebut menunjukan bahwa sebagian besar responden puas terhadap keluangan waktu petugas dalam memberikan pelayanan.

Dari ketiga data tersebut dapat ditarik kesimpulan bahwa tingkat kepuasan pasien berdasarkan dimensi daya tanggap (Responsivness) diperoleh rata-rata data skor sebesar 340,7 dengan rata-rata persentase interpretasi sebesar $75,7 \%$ yang menunjukan bahwa sebagian besar responden puas terhadap pelayanan berdasarkan dimensi daya tanggap (Responsivness). Hal ini dapat disebabkan oleh pelayanan telah sebanding dengan harapan pasien yang mana sikap tanggap petugas dalam membantu dan menyediakan jasa yang dibutuhkan pasien telah terpenuhi.

Tingkat kepuasan pasien berdasarkan dimensi jaminan (Assurance) diperoleh rata-rata data skor sebesar 325 dengan rata-rata persentase interpretasi skor sebesar $72,2 \%$ yang menunjukan bahwa sebagian besar responden puas terhadap pelayanan berdasarkan dimensi jaminan (Assurance). Hal ini dapat dikarenakan oleh jasa yang ditawarkan telah memberi jaminan keamanan kepada pasien sehingga pelayanan tersebut sebanding dengan harapan pasien.

Tingkat kepuasan pasien berdasarkan dimensi Perhatian (Emphaty) diperoleh rata-rata data skor sebesar 334,3 dengan rata-rata persentase interpretasi skorsebesar $74,3 \%$ yang menunjukan bahwa sebagian besar responden puas terhadap pelayanan berdasarkan dimensi perhatian (Emphaty). Hal ini dapat 
dikarenakan pelayanan sebanding dengan harapan para pasien yang mana pelayanan petugas dalam memberikan pemahaman akan kebutuhan dan kepentingan pasien telah terpenuhi.

\section{KESIMPULAN}

Setelah melakukan penelitian tentang tingkat kepuasan pasien terhadap kualitas pelayanan farmasi di Instalasi Farmasi RSI PKU Muhammadiyah Palangkaraya, maka diperoleh kesimpulan berdasarkan 5 dimensi kualitas jasa yang dikemukakan oleh Parasuranman, Zeithmal, dan Berry yaitu :

1. Bukti Langsung (Tangible) diperoleh rata-rata persentase interpretasi skor $76,1 \%$ yang masuk dalam kategori puas berdasarkan Skala Likert.

2. Kemampuan (Reliability) diperoleh ratarata persentase interpretasi skor 73,3\% yang masuk dalam kategori puas berdasarkan Skala Likert.

3. Daya Tanggap (Responisvness) diperoleh rata-rata persentase interpretasi skor $75,7 \%$ yang masuk dalam kategori puas berdasarkan Skala Likert.

4. Jaminan (Assurance) diperoleh rata-rata persentase interpretasi skor $72,2 \%$ yang masuk dalam kategori puas berdasarkan Skala Likert.

5.Perhatian (Emphaty) diperoleh rata-rata persentase interpretasi skor $74,3 \%$ yang masuk dalam kategori puas berdasarkan Skala Likert.

\section{Saran}

Dari hasil penelitian yang telah dilakukan, peneliti ingin memberikan saran, yaitu :

Instalasi Farmasi RSI PKU Muhammadiyah Palangkaraya perlu meningkatkan lagi kualitas pelayanan farmasi pada pasien rawat jalan menjadi predikat sangat puas yang akan berdampak kepada peningkatan kunjungan pasien.

\section{DAFTAR PUSTAKA}

Azwar, A. 1996. Menjaga Mutu Pelayanan Kesehatan. Jakarta: Pustaka Sinar Harapan.

Gerson, R.F. 2004. Mengukur Kepuasan Pelanggan. Jakarta: Lembaga Manajemen PPM.

Kotler, P Dan Amstrong, G. 1997. Principle Of Marketing. Seven Edition. Prentice Hall

Kotler, P dan Keller. 2007. Manajemen Pemasaran 2. Jakarta: PT. Indeks.

Muninjaya. 2014. Manajemen Mutu Pelayanan Kesehatan. Jakarta: EGC.

Manurung, L. 2010. Analisis Hubungan Tingkat Kepuasan Pasien Rawat Jalan Terhadap Pelayanan Instalasi Farmasi Dengan Minat Pasien Menebus Kembali Resep Obat Di Instalasi Farmasi RSUD Budhi Asih Tahun 2010. Jakarta: Skripsi. Universitas Indonesia.

Riduwan. 2017. Skala Pngukuran Variabelvariabel Penelitian. Bandung: Alfa Beta.

Siregar, S. 2010. Statistik Deskriptif Untuk Penelitian. Jakarta: Rajawali Pers. 
Sugiyono. 2015. Metode Penelitian

Kuantitatif, Kualitatif dan R\&D.

Bandung: Alfabeta.

Tjiptono,F dan Diana, A.2003.Service, Quality, And Satisfaction. Yogyakarta: Andi Offset.

Tjiptono,F. 2006. Manajemen Jasa Pelayanan Kesehatan. Yogyakarta: Andi Offset.

Umar.H. 2004. Metode Pelatihan Untuk Skripsi Dan Tesis Bisnis. Jakarta: PT. Raja Grafindo Prasada. 